\title{
Saprochaete clavata Infection in Immunosuppressed Patients: Systematic Review of Cases and Report of the First Oral Manifestation, Focusing on Differential Diagnosis
}

\author{
Carlo Lajolo ${ }^{1}$ (D) Cosimo Rupe ${ }^{1, *}$, Anna Schiavelli ${ }^{1}$, Gioele Gioco ${ }^{1}$, Elisabetta Metafuni ${ }^{2,3}$, Maria Contaldo ${ }^{4}$ \\ and Simona Sica 2,3
}

check for updates

Citation: Lajolo, C.; Rupe, C.;

Schiavelli, A.; Gioco, G.; Metafuni, E.; Contaldo, M.; Sica, S. Saprochaete clavata Infection in

Immunosuppressed Patients:

Systematic Review of Cases and

Report of the First Oral Manifestation,

Focusing on Differential Diagnosis.

Int. J. Environ. Res. Public Health 2021,

18, 2385. https://doi.org/10.3390/

ijerph18052385

Academic Editors: Paul Tchounwou and Denis Bourgeois

Received: 13 January 2021

Accepted: 24 February 2021

Published: 1 March 2021

Publisher's Note: MDPI stays neutral with regard to jurisdictional claims in published maps and institutional affiliations.

Copyright: (C) 2021 by the authors Licensee MDPI, Basel, Switzerland This article is an open access article distributed under the terms and conditions of the Creative Commons Attribution (CC BY) license (https:/ / creativecommons.org/licenses/by/ $4.0 /)$
1 Head and Neck Department, "Fondazione Policlinico Universitario A. Gemelli-IRCCS", School of Dentistry, Università Cattolica del Sacro Cuore, Largo A. Gemelli, 8, 00168 Rome, Italy; carlo.lajolo@policlinicogemelli.it (C.L.); anna.schiavelli@gmail.com (A.S.); gioele.gioco@gmail.com (G.G.)

2 Dipartimento di Diagnostica per Immagini, Radioterapia Oncologica ed Ematologia, Fondazione Policlinico Universitario A. Gemelli IRCCS, 00168 Rome, Italy; bettymetafuni@yahoo.it (E.M.); simona.sica@policlinicogemelli.it (S.S.)

3 Sezione di Ematologia, Dipartimento di Scienze Radiologiche ed Ematologiche, Università Cattolica del Sacro Cuore, 00168 Rome, Italy

4 Multidisciplinary Department of Medical-Surgical and Dental Specialties, University of Campania Luigi Vanvitelli, Via Luigi de Crecchio, 6, 80138 Naples, Italy; maria.contaldo@unicampania.it

* Correspondence: cosimo.rupe01@icatt.it

Abstract: Background: Saprochaete clavata infection is an emerging issue in immunosuppressed patients, causing fulminant fungaemia. The purpose of this systematic review of cases is to retrieve all cases of $S$. clavata infection and describe oral lesions as the first manifestation of $S$. clavata infection Methods: We report the first case of intraoral S. clavata infection in Acute Myeloid Leukemia (AML) affected subject, presenting as multiple grayish rapidly growing ulcerated swellings, and provide a review of all published cases of infection caused by $S$. clavata, according to PRISMA (Preferred Reporting Items for Systematic Reviews and Meta-Analyses) guidelines, conducted by searching SCOPUS, Medline, and CENTRAL databases. Only articles in English were considered. Individual patient data were analyzed to identify risk factors for S. clavata infection. Results: Seventeen of 68 retrieved articles were included in the review reporting data on 96 patients (mean age 51.8 years, 57 males and 38 females). Most cases were disseminated (86) with a $60.2 \%$ mortality rate. Ninety-five were hematological patients, with AML being the most common (57 cases). Conclusions: S. clavata infection in immunosuppressed patients has a poor prognosis: middle-age patients, male gender and Acute Myeloid Leukemia should be considered risk factors. In immunosuppressed patients, the clinical presentation can be particularly unusual, imposing difficult differential diagnosis, as in the reported case.

Keywords: Saprochaete clavata; Geotrichum clavatum; rare mycoses

\section{Introduction}

Opportunistic fungal infections represent a major cause of morbidity and mortality in patients with malignant hematological diseases [1-3]. Aspergillus and Candida species are the most frequent etiological agents, while Geotrichum genus has only recently been detected as an emerging opportunistic pathogen in hematological patients $[4,5]$.

Geotrichum is a ubiquitous, filamentous, yeast-like genus of fungi composed of 18 species, among which Geotrichum clavatum (reclassified as Saprochaete clavata) and Geotrichum capitatum (reclassified as Saprochaete capitata) are the most common pathogens for human infection [6].

The genus Geotrichum can be found worldwide in soil, water, air, wood, animals, and dairy products. Moreover, it has also been isolated as a commensal fungus in the 
respiratory secretions and gastrointestinal tract of Mediterranean subjects [7,8]. Orofecal transmission is the most common source of infection [9]; in particular, ingestion of cheese seems to be the most common way, as these fungi are used in cheese maturing.

When a S. clavata infection arises in immunosuppressed patients, it may cause fulminant fungaemia with multi-organ involvement and it has a $60 \%$ to $80 \%$ mortality rate. Disseminated infection initially arises with nonspecific symptoms (i.e., fever, diarrhea, and pulmonary symptoms), and most infections are mainly diagnosed by blood culture [10]. The clinical presentation in immunocompetent patients is less severe and rarely reported [11].

The most commonly reported risk factors associated with S. clavata infection include hematological malignancy, prolonged neutropenia, high-dose corticosteroid therapy, broadspectrum antibiotic therapy, previous gastrointestinal colonization, and central venous catheters [4,12-14].

The purpose of this systematic review of cases is to report all cases of $S$. clavata infection and to describe the first case of oral lesions as the first manifestation of $S$. clavata infection in an immunosuppressed subject, especially focusing on the differential diagnosis of the oral lesions.

\section{Methods}

The present systematic review was conducted according to the PRISMA (Preferred Reporting Items for Systematic Reviews and Meta-Analyses) guidelines. A comprehensive and systematic electronic search in Medline (via PubMed), Scopus, and the Cochrane Central Register of Controlled Trials (CENTRAL) from database inception to December 2020 was conducted. The date of the last search was 16 December 2020. The database search was conducted by using a combination of the following MeSH terms and free text words: "Saprochaete" OR "Geotrichum" AND "rare mycoses". A supplementary manual search was conducted for articles published from the journals' inception dates and December 2020 in the following journals: Oral Oncology; Clinical Oral Investigations; Journal of Oral Pathology and Medicine; Oral Surgery, Oral Medicine, Oral Pathology, and Oral Radiology; Head and Face Medicine; and Oral Diseases. In addition, the bibliographies of all the selected articles were reviewed. Inclusion criteria were: full papers; English literature; observational clinical studies, namely, case reports, perspective and retrospective (cohort and case-control) and randomized clinical trials (RCTs); patients who received an S. clavata infection. All of the articles reporting cases of $S$. clavata infection were included in this review. No exclusion criteria were applied. Two reviewers (C.R. and C.L.) conducted the screening, independently and in duplicate, by using specially designed data extraction forms. For each included article, the variables collected included the year of publication, country, number of patients, gender and age of patients, underlying disease, clinical manifestation of the infection, and the final outcome of patient. Any disagreements were resolved by a third reviewer (A.S.). All data collected were analyzed using a computer program (SPSS v 21.0, Chicago, IL, USA).

\section{Results}

The initial search of the electronic databases yielded 68 articles, and the manual search yielded 2 additional articles. In total, 46 articles were removed on the basis of the review of their titles and abstracts, reporting other fungal infections; thus, 22 full-text articles were selected. Of these studies, 17 were included in the review (Figure 1). 


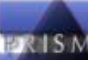

PRISMA 2009 Flow Diagram

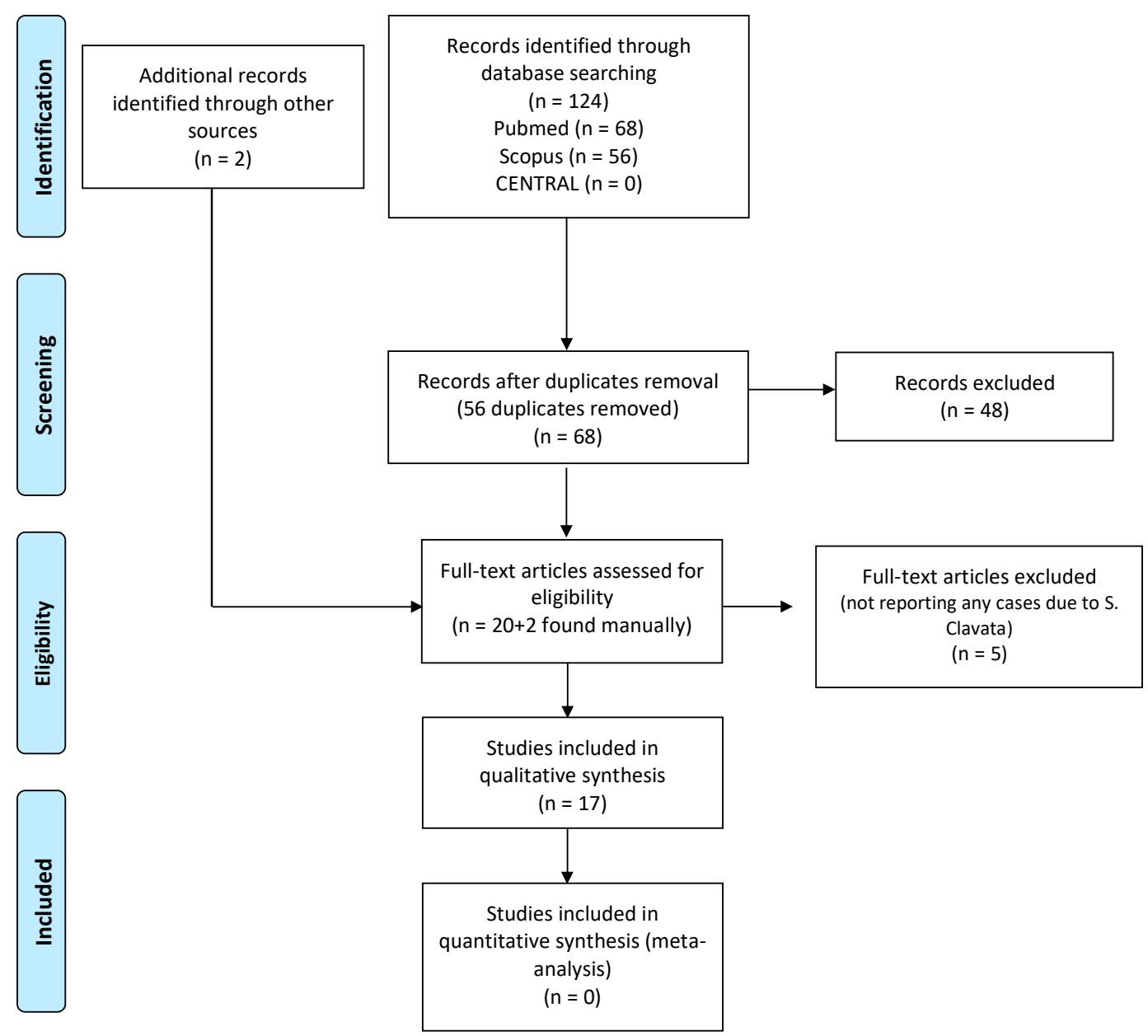

Figure 1. PRISMA (Preferred Reporting Items for Systematic Reviews and Meta-Analyses) flow-chart of the systematic review.

Pooled data from the literature review, stratified according to Geographic Distribution, Age, Gender, Anamnesis, and Clinical Features of patients, are shown in Table 1. This systematic review of the literature retrieved 96 cases of $S$. clavata infection. Most of the cases have been diagnosed in France ( 46 cases) or Italy (35 cases) and middle age (51.8 years) and male gender ( 57 males and 38 females) seem to be more frequently affected. Most cases were disseminated (86), leading to death $(60.2 \%$ of mortality rate). Other sites involved in the infection were gastrointestinal (24 patients had diarrhea) and pulmonary (27). Only one case arose with a single organ involvement (a splenic abscess). Considering the underlying immunodepression cause, 95 were hematological patients (comprising our case report) and only 1 was affected by polycystic kidney disease (PCKD). Among the hematological diseases, Acute Myeloid Leukemia was the most common (57 cases), whereas Lymphomas or Acute Lymphoid Leukemia were diagnosed in 12 and 10 cases, respectively. As concerning infection treatment, data about 48 patients were available; most of the patients (36) were treated by Azoles ( 30 patients by Voriconazole, 4 by Posaconazole). Other treatments were mainly based on Amphotericin B (27 patients), often in association with Azoles. 
Table 1. Pooled data from a literature review, stratified according to geographic distribution, age, gender, anamnesis, and clinical features.

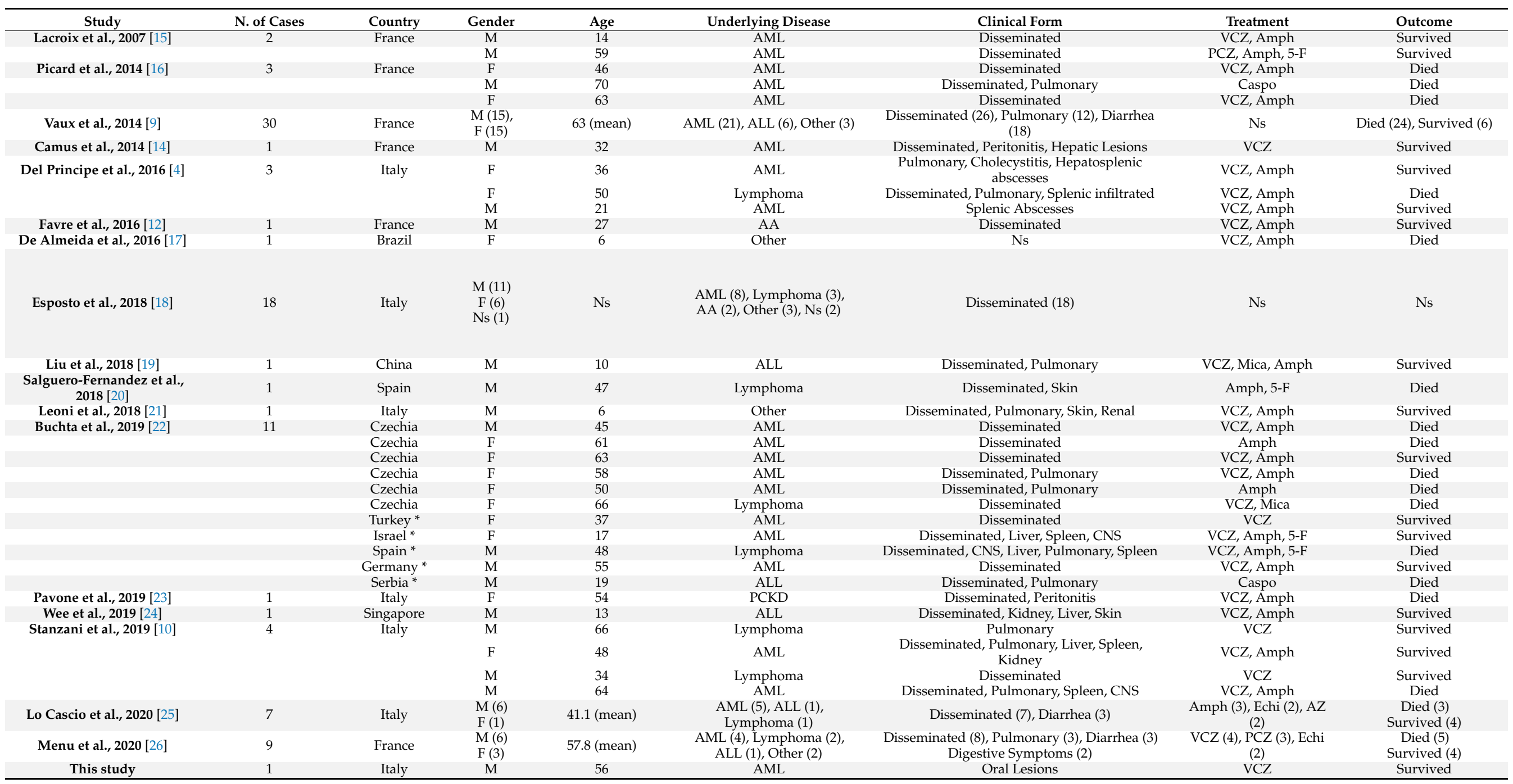

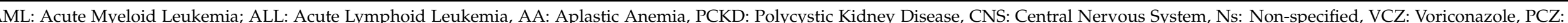

Posaconazole, Mica: Micafungin, Caspo: Caspofungin, Amph: Amphotericin B; Echi: Echinocandins; AZ: Azoles; 5-F: 5-fluorocytosine. * Cases retrieved by the international registry FungiScope. 


\section{Case Report}

A 56-year-old Caucasian man affected by acute myeloid leukemia (AML) was admitted to the Hematological Department of Policlinico A. Gemelli (Rome, Italy) for febrile neutropenia with multiple oral swellings. The patient's medical history revealed previous diagnoses of myelodysplastic syndrome (2016), refractory anemia with excess blasts type 1 (RAEB-1), which was treated with ten cycles of decitabine and an allogenic hematopoietic stem cell transplantation. This recurring disease evolved into Acute Myeloid Leukemia (2018). Consequently, re-induction chemotherapy was administered using Chlorambucil and Cytarabine first, followed by a combination of Azacitidine and Venetoclax. In October 2019, the patient was hospitalized for febrile neutropenia with severe thrombocytopenia. At that moment, the patient was receiving antifungal prophylaxis with Posaconazole $300 \mathrm{mg} /$ die. Blood culture was performed and the research for yeasts was negative. The physical examination did not retrieve any skin lesion. The oral examination revealed that three rapidly growing asymptomatic ulcerated swellings, located on both the buccal mucosa and the left mandible, arose 15 days before (Figures 2-4).

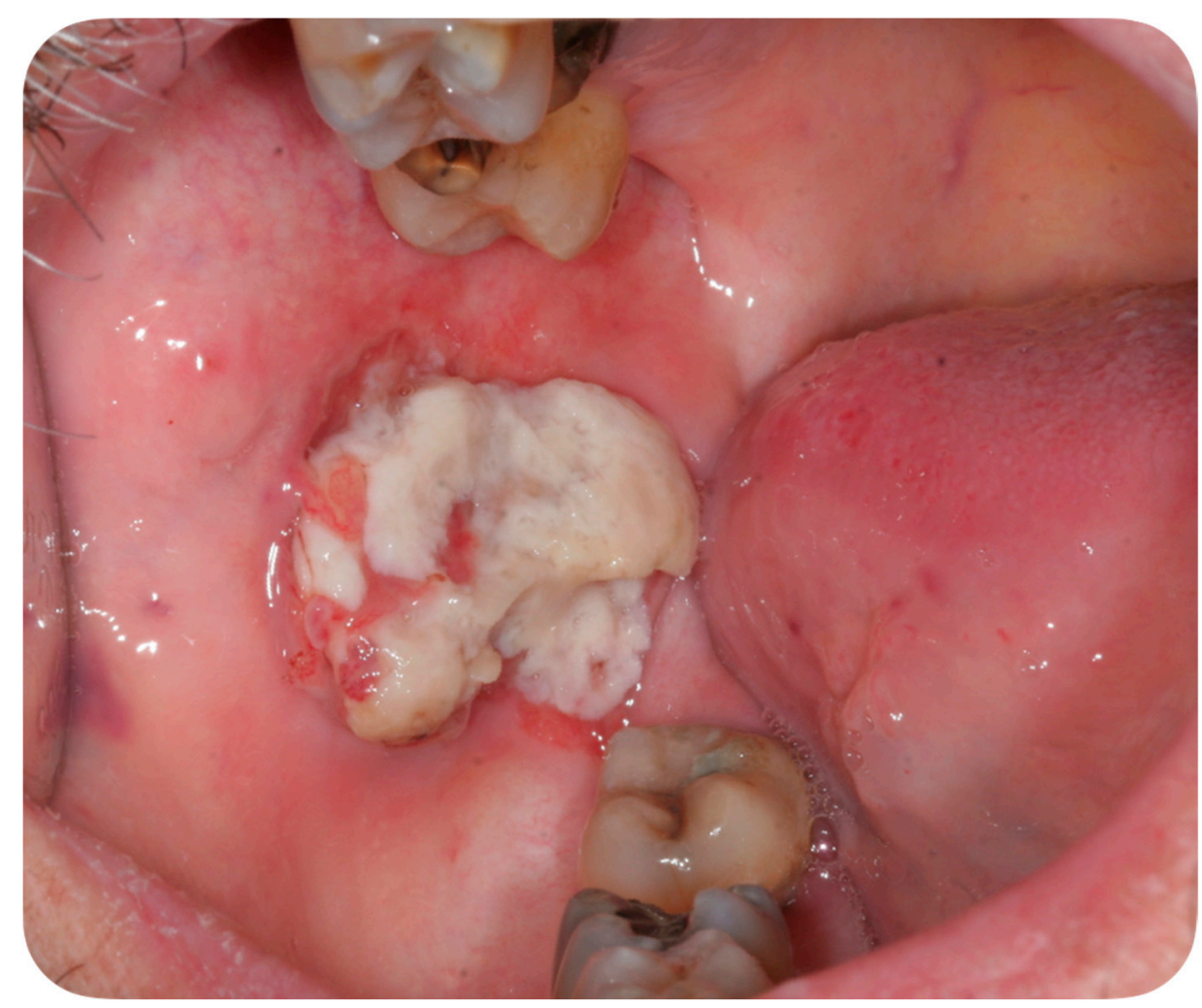

Figure 2. Asymptomatic ulcerated lesion, located on the right buccal mucosa. 


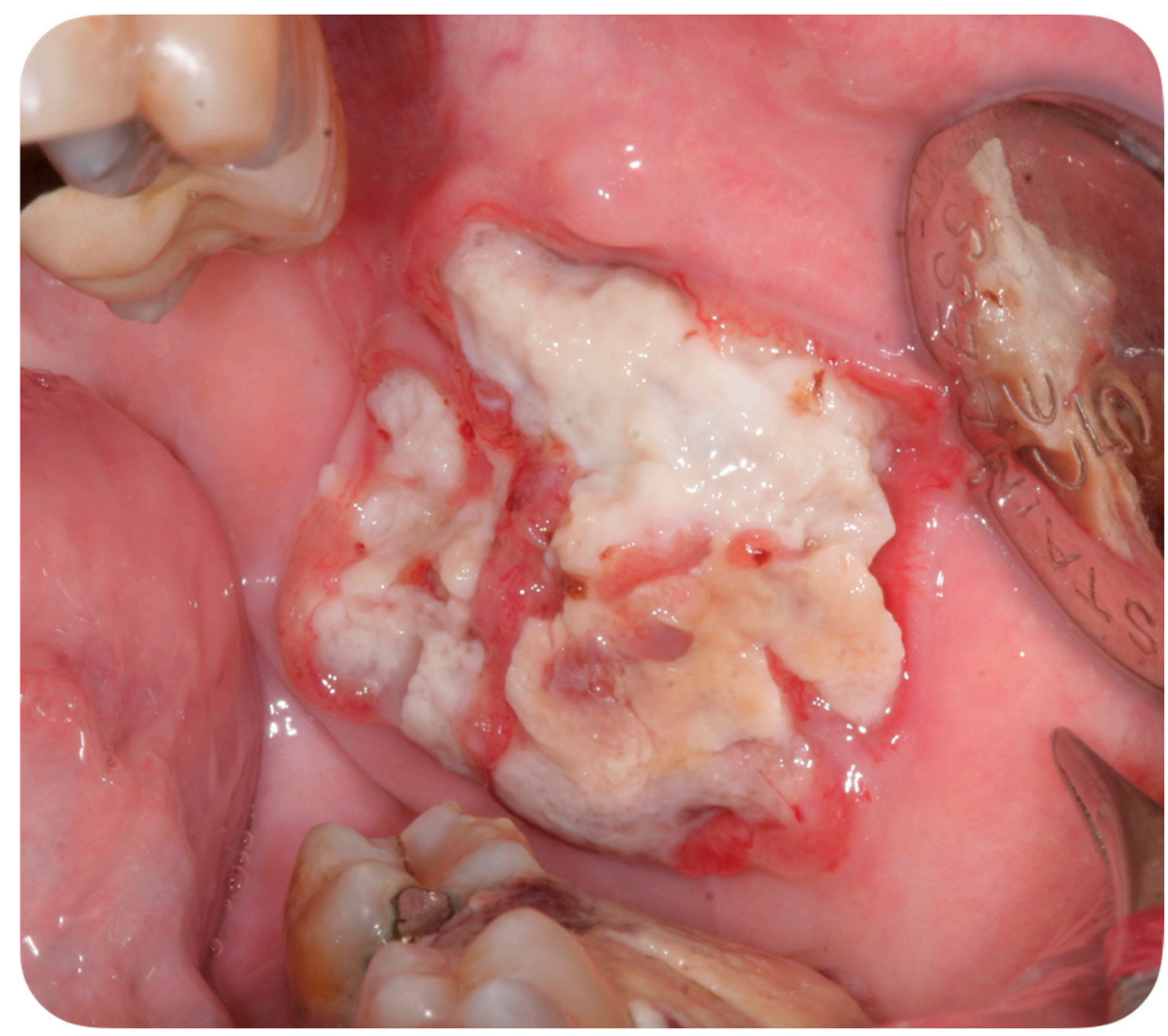

Figure 3. Asymptomatic ulcerated lesion, located on the left buccal mucosa.

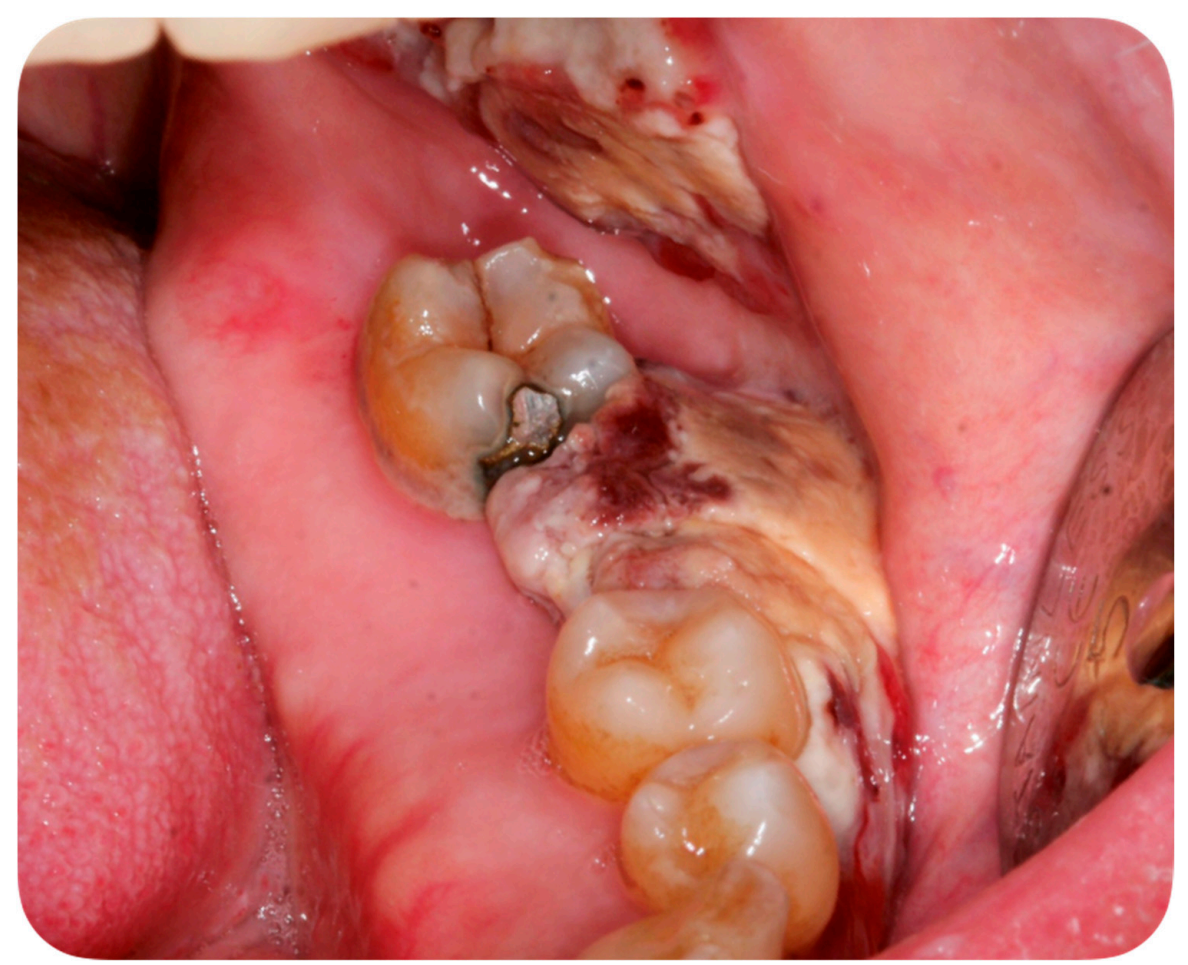

Figure 4. Asymptomatic ulcerated lesion, located on the left mandible.

Lesions were light-grayish in color, friable, with a $4 \mathrm{~cm}$ diameter, and protruded from the mucosa, interfering with chewing. After a platelet transfusion and local anesthesia (Carbocaine 2\% with epinephrine 1:100,000; Dentsply, Verona, Italy), an incisional biopsy was performed together with a microbiological sampling for fungi. The pathology 
revealed an inflammatory process in association with purulent necrosis and microbial colonies; no granulomas were detected in the specimen. Part of the sample was discharged in liquid Amies medium, then streak-plated on Sabouraud dextrose agar plates supplemented with gentamicin and chloramphenicol (Bio-Rad, Hercules, CA, USA) and BBL CHROMagar Candida plate (BD). We identified species using Bruker Biotyper version MBT 3.1 matrix-assisted laser desorption/ionization time-of-flight (MALDI-TOF) mass spectrometry (Bruker) and nucleotide sequence analysis of the internal transcribed spacer (ITS) regions of the rRNA gene. Microbiological sampling was thus positive for S. clavata, thus the final diagnosis indicated an intraoral fungal infection due to S. clavata. The Minimal inhibitory concentrantions (MICs) of antifungal drugs were determined in parallel according to the European Committee on Antimicrobial Susceptibility Testing (EUCAST) standardized broth microdilution method [27].

Given the results of the antifungal susceptibility testing, a therapy based on Voriconazole $200 \mathrm{mg}$ bid was set and resulted in the resolution of the oral lesions and improvement of the overall condition. Two weeks after the beginning of the therapy, the patient was dismissed, continuing the therapy with Voriconazole for two months. Nevertheless, in February 2020, the patient died from a worsening of his general conditions and underlying disease persistence.

\section{Discussion}

Deep fungal infections represent a major cause of morbidity and mortality in oncohematological patients undergoing immunosuppressing chemotherapies or those who have undergone bone marrow transplantation. In fact, fungi are responsible for approximately $20 \%$ of microbiologically documented intensive care unit (ICU) infections. In the last decade, the incidence of invasive fungal infections has steadily increased as a result of the increasing numbers of both immunocompromised and critically ill patients $[1-4,10,11,28]$.

In spite of this, the life expectancy of onco-hematological patients is rising thanks to improved diagnostic and therapeutical techniques; on the other side, the onco-hematological population is increasingly susceptible to rare infections, like $S$. clavata, which has been recognized as an emerging issue [5]. Three major sources of infection have been recognized: contaminated medical devices or dishes or dairy products have been advocated as major sources of S. clavata [9], but, considering published literature, the source of infection was unclear in the majority of the cases [26,28].

Even if the literature review identified only case reports and case series, probably due to the newly diagnosed entity, the articles included in this systematic review showed some results (Table 2) that should be taken into consideration for clinicians and future studies.

Table 2. Main results of the review. * Mortality rate was calculated excluding the articles not reporting the final outcome of patients.

\begin{tabular}{ll}
\hline Age & \\
\hline Years & 51.8 (mean) \\
Gender & 57 \\
Male & 38 \\
Female & 1 \\
Non-Specified & Tot 96 \\
Country & 46 \\
France & 35 \\
Italy & 6 \\
Czech & 9 \\
Other Countries (Spain, Germany, Brazil, Turkey, & Total Number (mortality rate *) \\
Israel, Serbia, China, Singapore) & $47(60.2 \%)$ \\
Outcome & $31(38.8 \%)$ \\
Death & \\
Survival & \\
\hline
\end{tabular}

S. clavata infection seems to be more common in males (57 to 38 patients), even if more diagnosed cases are needed to state that male gender is a risk factor for S. clavata infection. 
The mean age of affected patients was 51.8 years. Middle age should be considered as a risk factor for the development of this infection, even if our results showed how even younger or pediatric patients could be affected. In order to better assess the risk factors linked to this infection, clinical studies providing a higher level of evidence should be performed.

According to the available literature, the majority of patients affected by S. clavata had received a diagnosis of Acute Myeloid Leukemia and underwent a therapy based on Cytarabine, an antineoplastic drug that can alter digestive mucosa. It has been hypothesized that the mucosal alteration caused by Cytarabine allows $S$. clavata translocation from the gastrointestinal tract, thus promoting the diffusion and the infection [9]. Although this hypothesis could explain the pathogenetic mechanism favoring S. clavata infection, it is not clear why mainly hematological patients are affected compared to other immunosuppressed patients (95 to 1 in the reported cases) $[29,30]$.

Although S. clavata infection usually arises with nonspecific symptoms, it causes disseminated infection in almost all of the cases (86 out of 96 of the included cases), threatening the survival of infected patients. In this light, it is crucial to reach an early diagnosis in order to start the correct treatment.

Considering the treatment, three major classes of antifungal agents can be considered: polyenes, azoles, and echinocandins. Polyenes (i.e., amphotericin B, nystatin) bind to ergosterol of fungal membrane, causing its disruption (fungicidal); Azoles (i.e., Voriconazole, Itraconazole) act by inhibiting ergosterol synthesis in the endoplasmic reticulum of the fungal cell (fungistatic) and echinocandins (i.e., Caspofungin, Anidulafungin, Micafungin) and inhibit the synthesis of some components of the fungi cell wall. According to the available literature, S. clavata seems to be intrinsically resistant to echinocandins [31], whereas Voriconazole, Itraconazole, Posaconazole, Amphotericin B, and 5-fluorocytosine showed some efficacy [9,32]; Voriconazole appears to be the most suitable treatment since it has shown effectiveness both in vitro and in vivo $[3,9,14,33]$.

The results of this systematic review show how Voriconazole and Amphotericin B are the most used treatment: 5 patients were treated by Voriconazole alone, all of them survived. Two patients were treated by Amphotericin B alone, but their outcome was not successful. The association between these two drugs was the treatment of choice for the majority of patients (21): eleven of them survived, while 10 patients died. Although only scattered data could be obtained from our literature review, the hypothesis that Voriconazole is the most effective treatment can be supported, even if further studies are needed to confirm it.

Considering our experience, even if our patient was already, at the admission, undergoing a prophylactic treatment based on Posaconazole (300 mg die) to prevent opportunistic infections, the susceptibility testing confirmed that both Posaconazole and Voriconazole were effective drugs against $S$. clavata, but oral lesions healed only after the use of Voriconazole (200 $\mathrm{mg}$ bid): this strengthened the hypothesis that Voriconazole is the most effective treatment.

This case report describes the first case of oral lesions as the first manifestation of S. clavata infection and the literature review did not find any other case with oral involvement, thus differential diagnosis was particularly demanding. The infection manifested as three rapidly growing asymptomatic ulcerated swellings, located on both the buccal mucosa and the left mandible, that arose 15 days before. Lesions were light grayish in color, friable, with a $4 \mathrm{~cm}$ diameter, and protruded from the mucosa, interfering with chewing (Figure 1). Since clinical presentation of common and rare diseases can be really unusual in immunosuppressed patients, the diagnosis of these lesions was particularly challenging, but some clinical characteristics drove the differential diagnosis: rapid growth, ulcerating feature, bilateral onset, and absence of any other symptom (i.e., pain, itching, burning sensation). For these reasons, oral or deep fungal infections, other opportunistic infections, relapses, or new onset of hematological diseases and granulomatous diseases have been considered in the differential diagnosis (Table 3). 
Table 3. Differential diagnosis for oral manifestation of Saprochaete clavata.

\begin{tabular}{|c|c|c|c|c|c|c|}
\hline \multirow{2}{*}{ Clinical Entity } & \multirow{2}{*}{ Etiology and Pathogenesis } & \multicolumn{3}{|c|}{ Clinical Manifestation } & \multirow{2}{*}{ Diagnosis } & \multirow{2}{*}{$\begin{array}{l}\text { Reason for Exclusion during } \\
\text { the Diagnostic Flow-Chart }\end{array}$} \\
\hline & & Usual Features & Unusual Oral Presentation & Site & & \\
\hline \multicolumn{7}{|l|}{ Opportunistic Infections } \\
\hline Candidiasis [34] & C. Albicans and other C. spp. & $\begin{array}{l}\text { Pseudomembranous Candidiasis: } \\
\text { white, soft plaques, removable, } \\
\text { sometimes burning sensation } \\
\text { and altered taste. } \\
\text { Acute erythematous candidiasis: } \\
\text { Erythema, usually painful }\end{array}$ & $\begin{array}{l}\text { Rapidly growing exophytic } \\
\text { lesions }\end{array}$ & $\begin{array}{l}\text { Buccal mucosa } \\
\text { Palate } \\
\text { Dorsal tongue }\end{array}$ & Microbiological culture & $\begin{array}{l}\text { Usually do not comprise } \\
\text { rapidly growing asymptomatic } \\
\text { ulcerated swellings }\end{array}$ \\
\hline Aspergillosis & Aspergillus spp. & $\begin{array}{l}\text { Oral manifestations do not } \\
\text { arise in immunocompetent } \\
\text { hosts }\end{array}$ & $\begin{array}{l}\text { Invasive form: swelling, } \\
\text { ulceration, necrosis, usually } \\
\text { painful }\end{array}$ & $\begin{array}{l}\text { Paranasal sinuses } \\
\text { Oropharynx } \\
\text { Palate } \\
\text { Dorsal Tongue }\end{array}$ & Microbiological culture & $\begin{array}{l}\text { (a) Uncommon location of the } \\
\text { lesions } \\
\text { (b) Absence of symptoms } \\
\text { (c) Microbiological culture }\end{array}$ \\
\hline Histoplasmosis & H. Capsulatum & $\begin{array}{l}\text { Histoplasmosis of the head and } \\
\text { neck is rarely seen in } \\
\text { immunocompetent patients }\end{array}$ & $\begin{array}{l}\text { Rapidly growing asymptomatic } \\
\text { oral ulceration with firm } \\
\text { margins, single or multiple, } \\
\text { nonhealing. }\end{array}$ & $\begin{array}{l}\text { Tongue, } \\
\text { Palate, } \\
\text { Buccal mucosa }\end{array}$ & $\begin{array}{l}\text { Microbiological culture and } \\
\text { pathology }\end{array}$ & $\begin{array}{l}\text { (a) Oral Histoplasmosis usually } \\
\text { does not appear as a friable } \\
\text { swelling } \\
\text { (b) Medical history: no travels } \\
\text { in US } \\
\text { (c) Microbiological culture and } \\
\text { pathology }\end{array}$ \\
\hline Syphilis $[35,36]$ & T. Pallidum & $\begin{array}{l}\text { Primary syphilis indurated ulcer, } \\
\text { asymptomatic. } \\
\text { Secondary syphilis: red rash } \\
\text { characterized by } \\
\text { maculopapular areas, oral } \\
\text { ulcers covered by membrane, } \\
\text { or condyloma lata }\end{array}$ & $\begin{array}{l}\text { Vascular proliferation, multiple } \\
\text { ulcerated areas, hemorrhage }\end{array}$ & $\begin{array}{l}\text { Lips, but any other site can be } \\
\text { involved }\end{array}$ & $\begin{array}{l}\text { Direct detection of T. pallidum } \\
\text { and serologic testing } \\
\text { (treponemal and } \\
\text { non-treponemal tests, i.e., } \\
\text { TPHA) }\end{array}$ & $\begin{array}{l}\text { (a) Negative TPHA } \\
\text { (b) Absence of characteristic } \\
\text { systemic symptoms (secondary } \\
\text { syphilis) } \\
\text { (c) Pathology (absence of } \\
\text { proliferative endarteritis and } \\
\text { infiltration of plasma cells) }\end{array}$ \\
\hline Tuberculosis [37] & Mycobacterium Tuberculosis & $\begin{array}{l}\text { Oral lesions are uncommon and } \\
\text { occur due to infected sputum } \\
\text { or hematogenous spread }\end{array}$ & $\begin{array}{l}\text { Chronic and indurated ulcer, } \\
\text { non-healing extraction sockets, } \\
\text { osteomyelitis, and mandibular } \\
\text { swellings. }\end{array}$ & $\begin{array}{l}\text { Tongue and palate but any } \\
\text { mucosal surface can be } \\
\text { involved. } \\
\text { Bone of maxilla or mandible }\end{array}$ & $\begin{array}{l}\text { Molecular tests (nucleic acid } \\
\text { amplification test-Xpert } \\
\text { MTB/RIF), Pathology, } \\
\text { microbiological tests } \\
\text { (mycobacterial growth } \\
\text { indicator tube-MGIT) }\end{array}$ & $\begin{array}{l}\text { (a) Pathology (absence of } \\
\text { typical caseous tuberculous } \\
\text { granulomas) } \\
\text { (b) Clinical presentation: } \\
\text { Tuberculosis oral lesions } \\
\text { usually have an "infiltrating" } \\
\text { feature more than exophytic }\end{array}$ \\
\hline Actinomycosis $[38,39]$ & Actinomyces spp. & $\begin{array}{l}\text { Fibrosis, swellings, cutaneous } \\
\text { draining sinus tracts }\end{array}$ & $\begin{array}{l}\text { Ulcerations of the tongue and } \\
\text { osteomyelitis. One reported } \\
\text { case of involvement of floor of } \\
\text { the mouth and buccal mucosa }\end{array}$ & $\begin{array}{l}\text { Mandible and surrounding } \\
\text { tissues. Salivary glands }\end{array}$ & $\begin{array}{l}\text { Microbiological culture and } \\
\text { pathology }\end{array}$ & $\begin{array}{l}\text { Microbiological culture and } \\
\text { pathology (absence of } \\
\text { granulomatous inflammatory } \\
\text { response) }\end{array}$ \\
\hline \multicolumn{7}{|l|}{ Malignant Diseases } \\
\hline Lymphomas [40-42] & $\begin{array}{l}\text { Heterogeneous malignant } \\
\text { disease of the lymphatic system }\end{array}$ & $\begin{array}{l}\text { Hodgkin's lymphomas: very rare } \\
\text { in the oral cavity. } \\
\text { Non-Hodgkin's lymphomas: } \\
\text { rapidly growing asymptomatic } \\
\text { ulcerated swellings, bone } \\
\text { resorption, or bone loss }\end{array}$ & $\begin{array}{l}\text { Pathologic fracture. Pain, } \\
\text { numbness of the lip. }\end{array}$ & $\begin{array}{l}\text { Tonsils, } \\
\text { Salivary glands, } \\
\text { maxilla, } \\
\text { base of the tongue, } \\
\text { Soft palate }\end{array}$ & $\begin{array}{l}\text { Histopathological examination } \\
\text { (presence of Reed-Stemberg cells } \\
\text { for Hodgkin's lymphomas), } \\
\text { immunophenotyping, flow } \\
\text { cytometry }\end{array}$ & $\begin{array}{l}\text { Pathology and } \\
\text { immunohistochemistry } \\
\text { according to the lymphoma } \\
\text { type }\end{array}$ \\
\hline
\end{tabular}


Table 3. Cont

\begin{tabular}{|c|c|c|c|c|c|c|}
\hline \multirow{2}{*}{ Clinical Entity } & \multirow{2}{*}{ Etiology and Pathogenesis } & \multicolumn{3}{|c|}{ Clinical Manifestation } & \multirow{2}{*}{ Diagnosis } & \multirow{2}{*}{$\begin{array}{l}\text { Reason for Exclusion during } \\
\text { the Diagnostic Flow-Chart }\end{array}$} \\
\hline & & Usual Features & Unusual Oral Presentation & Site & & \\
\hline Verrucous Carcinoma $[43,44]$ & $\begin{array}{l}\text { Exophytic variant of oral } \\
\text { squamous cell carcinoma }\end{array}$ & $\begin{array}{l}\text { Plaque-like or exophytic mass } \\
\text { typically white, with a warty, } \\
\text { ulcerated, or papillary surface. } \\
\text { Slow continuous growth rate. } \\
\text { Usually painless }\end{array}$ & $\begin{array}{l}\text { Bone involvement (especially if } \\
\text { invasive transformation occurs) }\end{array}$ & $\begin{array}{l}\text { Buccal mucosa, } \\
\text { Gingiva }\end{array}$ & $\begin{array}{l}\text { Pathology (well-differentiated } \\
\text { epithelial cells mass extending } \\
\text { into the connective tissue } \\
\text { generally with a pushing } \\
\text { appearance) }\end{array}$ & $\begin{array}{l}\text { (a) Pathology } \\
\text { (b) Rapid onset } \\
\text { (c) Multiple lesions }\end{array}$ \\
\hline \multicolumn{7}{|l|}{ Orofacial Granulomatosis } \\
\hline Wegener Granulomatosis [45] & $\begin{array}{l}\text { Rare immune-based } \\
\text { inflammatory necrotizing } \\
\text { vasculitis of unknown cause }\end{array}$ & $\begin{array}{l}\text { Strawberry gingivitis, sinusitis, } \\
\text { oral ulceration }\end{array}$ & $\begin{array}{l}\text { Facial paralysis, Labial mucosal } \\
\text { nodules, } \\
\text { Necrosis and perforation of the } \\
\text { nasal septum or palate, } \\
\text { Swelling and desquamation of } \\
\text { the lips, } \\
\text { Salivary gland enlargement, } \\
\text { Arthralgia of the TMJ } \\
\text { Tongue involvement }\end{array}$ & $\begin{array}{l}\text { Gingiva but any mucosal } \\
\text { surface can be involved. } \\
\text { Rarely major salivary glands }\end{array}$ & $\begin{array}{l}\text { Pathology } \\
\text { Clinical diagnostic criteria } \\
\text { Presence of proteinase-3 } \\
\text { antineutrophil cytoplasm } \\
\text { antibodies (PR3-ANCA) } \\
\text { myeloperoxidase } \\
\text { antineutrophil cytoplasm } \\
\text { antibodies (MPO-ANCA) }\end{array}$ & $\begin{array}{l}\text { (a) Pathology (absence of } \\
\text { granulomatous lesions, with } \\
\text { necrotizing vasculitis) } \\
\text { (b) Absence of clinical } \\
\text { diagnostic criteria (Oral } \\
\text { ulcerations or nasal discharge, } \\
\text { nodules on chest radiograph, } \\
\text { abnormal urinary sediment, } \\
\text { granulomatous inflammation } \\
\text { upon biopsy) }\end{array}$ \\
\hline Crohn's Disease [46,47] & $\begin{array}{l}\text { Chronic inflammatory disease } \\
\text { of the gastrointestinal tract }\end{array}$ & $\begin{array}{l}\text { Ulcers, diffuse or nodular } \\
\text { swellings, cobblestone } \\
\text { appearance of the mucosa, } \\
\text { macules and plaques involving } \\
\text { the gingiva }\end{array}$ & $\begin{array}{l}\text { Angular cheilitis } \\
\text { Alveolar bone loss }\end{array}$ & $\begin{array}{l}\text { Lips } \\
\text { Gingiva } \\
\text { Buccal mucosa }\end{array}$ & $\begin{array}{l}\text { Endoscopy } \\
\text { Pathology }\end{array}$ & $\begin{array}{l}\text { (a) Pathology (absence of } \\
\text { classic non-caseating granulomas) } \\
\text { (b) Absence of peculiar clinical } \\
\text { features }\end{array}$ \\
\hline $\begin{array}{l}\text { Melkersson-Rosenthal } \\
\text { Syndrome [49] }\end{array}$ & $\begin{array}{l}\text { Rare disorder of unknown } \\
\text { cause }\end{array}$ & $\begin{array}{l}\text { Recurring facial paralysis, } \\
\text { swelling of the lips, and a } \\
\text { fissured tongue }\end{array}$ & $\begin{array}{l}\text { Edema, ulcers, papules, } \\
\text { swellings, cobblestone mucosal } \\
\text { alterations, or focal areas of } \\
\text { submucosal enlargement }\end{array}$ & $\begin{array}{l}\text { Lips } \\
\text { Tongue }\end{array}$ & $\begin{array}{l}\text { Pathology } \\
\text { Clinical diagnostic criteria }\end{array}$ & $\begin{array}{l}\text { (a) Pathology (absence of } \\
\text { classic non-caseating granulomas) } \\
\text { (b) Absence of clinical } \\
\text { diagnostic criteria } \\
\text { (labial swelling, facial paralysis, } \\
\text { and fissured tongue) }\end{array}$ \\
\hline
\end{tabular}


Candida and Aspergillus are the most common opportunistic fungal infections affecting the oral cavity [5]. In this case, oral candidiasis was excluded because its most common clinical presentations (Pseudomembranous Candidiasis and Acute erythematous candidiasis) do not comprise rapidly growing asymptomatic ulcerated swellings; nevertheless, a microbiological culture was performed to exclude C. albicans and other species infection or its superimposed infection.

Aspergillosis is a fungal disease characterized by noninvasive and invasive forms; in immunocompromised hosts, the invasive form can cause disseminated and life-threatening infections. This opportunistic fungal infection is reported as the second most prevalent one worldwide [50]. Aspergillosis spores can colonize the brain, the bones, the lungs, or the endocardium [5,51-54]. Signs and symptoms that may affect the head and neck district include sinusitis, oropharyngeal colonization, pain, swelling, ulceration, necrosis, and palatal perforation. In addition, the hyphae are able to penetrate the oral mucosa and the arterial wall, which may lead to hematogenous spread, thrombosis, or infarction [55,56]. Considering the clinical presentation of our case, oral Aspergillosis lesions arise generally as swelling with a necrotic ulcerated base, classically located on the palate or posterior tongue [5]. Nevertheless, microbiological culture on the biopsy sample was performed to exclude the diagnosis of oral Aspergillosis.

Histoplasmosis is another clinical entity that can appear as a rapidly growing asymptomatic oral ulceration. Although it is the most common fungal infection in the United States, Histoplasmosis in Europe is rare [57]. Almost 95\% of the immunocompetent patients that are exposed to the Histoplasma capsulatum never develop symptoms [58]. Yet, inhaling a large number of spores can cause symptoms even among healthy patients. Histoplasmosis has two manifestations: acute or chronic/disseminated. Only this latter form can affect the oral mucosa, causing painful chronic ulcerations, single or multiple, nonhealing and indurated [59]. The hypothesis of a case of Histoplasmosis was rejected according to the medical history of the patient, thanks to microbiological culture and pathology.

Among other infections, Syphilis, Tuberculosis, and Actinomycosis must be considered in the differential diagnosis. Treponema Pallidum infection in immunosuppressed individuals can cause diffused ulcerations of the oral cavity, with severe clinical appearance. Nevertheless, in our case, the TPHA (Treponema Pallidum Hemoagglutination Assay) was negative at admission in the hospital [60,61]. Tuberculosis causes ulcerations as well, affecting mainly the tongue and the palate, and usually have an "infiltrating" feature more than exophytic [62]; furthermore, pathology can reveal typical caseous tuberculous granulomas which can drive the diagnosis.

Actinomycosis is a chronic bacterial disease that may affect jaws after traumas, surgeries, previous infections, or in patients with other diseases. In the head and neck region, the condition appears as swelling associated with osteomyelitis and often with one or more draining, from the medullary spaces to skin or sinuses [63]. Only a few cases of ulcerations on the tongue associated with A. israelii have been reported in the literature [48]. This diagnosis has been excluded after the microbiological culture on the biopsied specimen.

Considering other malignancies, lymphomas can appear as rapidly growing asymptomatic ulcerated swellings: Hodgkin's lymphomas are very rare in the oral cavity but can affect the neck district, whereas, for non-Hodgkin's lymphomas, the head and neck region represents the second most common extra-nodal site [41,64]. Thus, a relapse of Acute Myeloid Leukemia or a new manifestation of any other hematological malignancy was excluded through pathology, which revealed an inflammatory process in association with purulent necrosis and microbial colonies. Considering other non-hematological malignancies, only verrucous carcinoma could be considered, but the rapid onset and the multifocal nature of these lesions immediately excluded such diagnosis; the following pathology confirmed the exclusion.

Finally, some orofacial granulomatosis should be considered in the differential diagnosis since most of them can present as oral ulcerated swellings. Wegener granulomatosis, Crohn's disease, sarcoidosis, and Melkersson-Rosenthal Syndrome are the most relevant. 
Wegener granulomatosis is a rare immune-based inflammatory necrotizing vasculitis of unknown cause, classically characterized by involvement of upper respiratory tract, lungs, and kidneys. The typical oral manifestation is strawberry gingivitis; less frequent findings include oral ulceration, necrosis, and perforation of the nasal septum or palate.

Crohn's disease may affect the gastrointestinal tract from mouth to anus. A wide range of nonspecific oral lesions has been associated with this condition, including ulcers (aphthous-like, with a granulomatous appearing, or linear aspect), diffuse or nodular swellings, a cobblestone appearance of the mucosa, or macules and plaques involving the gingiva.

Sarcoidosis is a multisystem granulomatous disease of unknown cause that can affect any organ but the lungs, the lymph nodes, the skin, the eyes, and the salivary glands are the predominant sites. Oral lesions may occur on any surface, in most cases, as a submucosal mass, ulceration, a nodular swelling, an area of granularity, or an isolated papule. When this condition is characterized by recurring facial paralysis, swelling of the lips and a fissured tongue is called Melkersson-Rosenthal Syndrome.

Melkersson-Rosenthal Syndrome intraoral lesions can include edema, ulcers, papules, swellings, cobblestone mucosal alterations, or focal areas of submucosal enlargement.

For all these entities, pathology reveals the presence of classic non-caseating granulomas together with some peculiar clinical features (i.e., abdominal pain, diarrhea, rectal blood loss, facial nerve paralysis) [65] or laboratory tests which can help in differentiating each other (i.e., presence of proteinase-3 antineutrophil cytoplasm antibodies-PR3-ANCA, myeloperoxidase antineutrophil cytoplasm antibodies-MPO-ANCA, elevated serum angiotensin-converting enzyme (ACE) levels) [66]. All these diseases were excluded since no granulomas were detected in the oral biopsy.

\section{Conclusions}

S. clavata infection may cause fulminant fungaemia with multi-organ involvement in immunosuppressed patients with a $60.2 \%$ mortality rate: middle-age patients, male gender and Acute Myeloid Leukemia should be considered risk factors. Some reports highlighted that previous therapy with Cytarabine should be considered as a further risk factor. Our case is the first report of intraoral lesions as the first manifestation of S. clavata in an immunodeficient patient. Proliferative oral lesions in the immunosuppressed hematological subject are always challenging for the oral medicine doctor since the immune system response of these patients is abnormal: numerous benign and malignant diseases (i.e., lymphoma, other hematological malignancies, infectious diseases, granulomatous diseases) must be excluded. In this regard, microbiological sampling is fundamental in order to exclude rare mycotic infections.

Author Contributions: Conceptualization, all authors; methodology, C.L. and C.R.; validation, C.L. and S.S.; formal analysis, C.L. and C.R.; investigation, C.R., A.S., E.M., and G.G.; data curation, C.R. and A.S.; writing - original draft preparation, C.L., C.R., and A.S.; writing — review and editing, C.L. and C.R.; visualization, S.S., E.M., and M.C.; supervision, C.L. and S.S. All authors have read and agreed to the published version of the manuscript.

Funding: This research received no external funding.

Informed Consent Statement: Informed consent was obtained from all subjects involved in the study.

Data Availability Statement: Not Applicable.

Conflicts of Interest: The authors declare no conflict of interest.

\section{References}

1. Miceli, M.H.; Kauffman, C.A. Isavuconazole: A new broad-spectrum triazole antifungal agent. Clin. Infect. Dis. 2015, 61, 1558-1565. [CrossRef] [PubMed]

2. Armstrong-James, D.; Bicanic, T.; Brown, G.D.; Hoving, J.C.; Meintjes, G.; Nielsen, K. AIDS-related mycoses: Current progress in the field and future priorities. Trends Microbiol. 2017, 26, 428-430. [CrossRef] [PubMed] 
3. Girmenia, C.; Pagano, L.; Martino, B.; D’Antonio, D.; Fanci, R.; Specchia, G.; Melillo, L.; Buelli, M.; Pizzarelli, G.; Venditti, M.; et al. Invasive infections caused by Trichosporon species and Geotrichum capitatum in patients with hematologic Malignancies: A Retrospective Multicenter Study from Italy and Review of the Literature. J. Clin. Microbiol. 2005, 43, 1818-1828. [CrossRef]

4. Del Principe, M.; Sarmati, L.; Cefalo, M.; Fontana, C.; De Santis, G.; Buccisano, F.; Maurillo, L.; De Bellis, E.; Postorino, M.; Sconocchia, G.; et al. A cluster of Geotrichum clavatum (Saprochaete clavata) infection in haematological patients: A first Italian report and review of literature. Mycoses 2016, 59, 594-601. [CrossRef]

5. Deepa, A.; Nair, B.; Sivakumar, T.; Joseph, A. Uncommon opportunistic fungal infections of oral cavity: A review. J. Oral Maxillofac. Pathol. 2014, 18, 235-243. [CrossRef] [PubMed]

6. Pottier, I.; Gente, S.; Vernoux, J.; Guéguen, M. Safety assessment of dairy microorganisms: Geotrichum candidum. Int. J. Food Microbiol. 2008, 126, 327-332. [CrossRef] [PubMed]

7. Miceli, M.; Lee, S. Emerging moulds: Epidemiological trends and antifungal resistance. Mycoses 2011, 54, e666-e678. [CrossRef]

8. Gadea, I.; Cuenca, E.M.; Prieto, E. Genotyping and antifungal susceptibility profile of Dipodascus capitatus isolates causing disseminated infection in seven hematological patients of a tertiary hospital. J. Clin. Microbiol. 2004, 42, 1832-1836. [CrossRef]

9. Vaux, S.; Criscuolo, A.; Desnos Ollivier, M.; Diancourt, L.; Tarnaud, C.; Vandenbogaert, M.; Brisse, S.; Coignard, B.; Dromer, F. Geotrichum Investigation Group. Multicenter outbreak of infections by Saprochaete clavata, an unrecognized opportunistic fungal pathogen. Mbio 2014, 5, 02309-02314. [CrossRef]

10. Stanzani, M.; Cricca, M.; Sassi, C.; Sutto, E.; De Cicco, G.; Bonifazi, F.; Bertuzzi, C.; Bacci, F.; Paolini, S.; Cavo, M.; et al. Saprochaete clavata infections in patients undergoing treatment for haematological malignancies: A report of a monocentric outbreak and review of the literature. Mycoses 2019, 62, 1100-1107. [CrossRef]

11. El Zein, S.; Hindy, J.; Kanj, S. Invasive Saprochaete Infections: An Emerging Threat to Immunocompromised Patients. Path-Ogens 2020, 9, 922. [CrossRef]

12. Favre, S.; Rougeron, A.; Levoir, L.; Pérard, B.; Milpied, N.; Accoceberry, I.; Gabriel, F.; Vigouro, S. Saprochaete clavata invasive infection in a patient with severe aplastic anemia: Efficacy of voriconazole and liposomal amphotericin B with adjuvant granulocyte transfusions before neutrophil recovery following allogeneic bone marrow transplantation. Med. Mycol. Case Rep. 2016, 11, 21-23. [CrossRef]

13. Fernández-Ruiz, M.; Guinea, J.; Puig Asensio, M.; Zaragoza, Ó.; Almirante, B.; Cuenca-Estrella, M.; Aguado, J.M.; CANDIPOP Project, GEIH-GEMICOMED (SEIMC) and REIPI. Fungemia due to rare opportunistic yeasts: Data from a population-based surveil-lance in Spain. Med. Mycol. 2017, 55, 125-136. [CrossRef]

14. Camus, V.; Thibault, M.; David, M.; Gargala, G.; Compagnon, P.; Lamoureux, F.; Girault, C.; Michot, J.; Stamatoullas, A.; Lanic, H.; et al. Invasive Geotrichum clavatum fungal infection in an acute myeloid leukaemia patient: A case report and review. Mycopathologia 2014, 177, 319-324. [CrossRef]

15. Lacroix, C.; Brethon, B.; Boissel, N.; Desnos, M.; Leblanc, T.; Raffoux, E. Geotrichum clavatum an emerging pathogen responsible for invasive infection in two neutropenic leukemia patients. J. Chemother. 2007, 19, 81.

16. Picard, M.; Cassaing, S.; Letocart, P.; Verdeil, X.; Protin, C.; Chauvin, P.; Iriart, X.; Cavalié, L.; Valentin, A.; Marchou, B.; et al. Concomitant cases of disseminated Geotrichum clavatum infections in patients with acute myeloid leukemia. Leuk. Lymphoma 2014, 55, 1186-1188. [CrossRef] [PubMed]

17. De Almeida Júnior, J.; Sztajnbok, J.; da Silva, A.; Vieira, V.; Galastri, A.; Bissoli, L.; Litvinov, N.; del Negro, G.M.B.; Motta, A.L.; Rossi, F.; et al. Rapid identification of moulds and arthroconidial yeasts from positive blood cultures by MALDI-TOF mass spectrometry. Med. Mycol. 2016, 54, 885-889. [CrossRef] [PubMed]

18. Esposto, M.; Prigitano, A.; Lo Cascio, G.; Ossi, C.; Grancini, A.; Cavanna, C.; Lallitto, F.; Tejada, M.; Bandettini, R.; Mularoni, A.; et al. Yeast-like filamentous fungi: Molecular identification and in vitro susceptibility study. Med. Mycol. 2018, 57, 909-913. [CrossRef] [PubMed]

19. Liu, X.; Zhou, W.; Jiang, Y.; Kuang, L. Invasive fungal infection caused by Geotrichum clavatum in an acute leukemia child: First documented case from mainland China. JPN J. Infect. Dis. 2018, 72, 130-132. [CrossRef] [PubMed]

20. Salguero Fernández, I.; Nájera Botello, L.; Orden Martinez, B.; Roustan Gullón, G. Disseminated fungemia by Saprochaete clavata. Enferm. Infecc. Microbiol. Clin. 2018, 37, 283-284. [CrossRef] [PubMed]

21. Leoni, M.; Riccardi, N.; Rotulo, G.A.; Godano, E.; Faraci, M.; Bandettini, R.; Esposto, M.C.; Castagnola, E. Magnusiomyces clavatus infection in a child after allogeneic hematotopoetic stem cell transplantation: Diagnostic and therapeutic implications. Med. Mycol. Case Rep. 2018, 23, 65-67. [CrossRef]

22. Buchta, V.; Bolehovská, R.; Hovorková, E.; Cornely, O.; Seidel, D.; Žák, P. Saprochaete clavata Invasive Infections-A New Threat to Hematological-Oncological Patients. Front Microbiol. 2019, 10, 2196. [CrossRef] [PubMed]

23. Pavone, P.; Oliva, A.; Raponi, G.; Pugliese, F.; Martelli, S.; Celli, P.; Saccoa, F.; Vullo, V.; Mastroianni, C.M.; Russo, G. Disseminated fungal infection due to Saprochaete clavata in a kidney transplant recipient. J. Mycol. Med. 2019, 3, 278-281. [CrossRef]

24. Wee, L.; Ling, H.; Chong, C.; Soe, M.; Koh, M. A rare case of purpuric rash caused by Saprochaete clavata in a pediatric patient with acute leukemia. Pediatr. Dermatol. 2019, 6, 990-991. [CrossRef] [PubMed]

25. Lo Cascio, G.; Vincenzi, M.; Soldani, F.; De Carolis, E.; Maccacaro, L.; Sorrentino, A.; Nadali, G.; Cesaro, S.; Sommavilla, M.; Niero, V. Outbreak of Saprochaete clavata Sepsis in Hematology Patients: Combined Use of MALDI-TOF and Sequencing Strategy to Identify and Correlate the Episodes. Front. Microbiol. 2020, 11, 84. [CrossRef] 
26. Menu, E.; Criscuolo, A.; Desnos-Ollivier, M.; Cassagne, C.; D’Incan, E.; Furst, S.; Ranque, S.; Berger, P.; Dromer, F. Saprochaete clavata Outbreak Infecting Cancer Center through Dishwasher. Emerg. Infect. Dis. 2020, 26, 2031-2038. [CrossRef] [PubMed]

27. Arendrup, M.C.; Cuenca-Estrella, M.; Lass-Flörl, C.; Hope, W.; EUCAST-AFST. EUCAST technical note on the EUCAST definitive document EDef 7.2: Method for the determination of broth dilution minimum inhibitory concentrations of antifungal agents for yeasts EDef 7.2 (EUCAST-AFST). Clin. Microbiol. Infect. 2012, 7, E246-E247. [CrossRef] [PubMed]

28. Durán, G.; Seidel, D.; Vehreschild, M.; Hamprecht, A.; Kindo, A.; Raci, Z.; Demeter, J.; de Hoog, S.; Aurbach, U.; Ziegler, M.; et al . Invasive infections due to Saprochaete and Geotrichum species: Report of 23 cases from the FungiScope Registry. Mycoses 2017, 60, 273-279. [CrossRef]

29. Camera, A.; Andretta, C.; Villa, M.; Volpicelli, M.; Picardi, M.; Rossi, M.; Rinaldi, C.R.; della Cioppa, P.; Ciancia, R.; Selleri, C.; et al. Intestinal toxicity during induction chemotherapy with cytarabine-based regimens in adult acute myeloid leukemia. Hematol. J. 2003, 4, 346-350. [CrossRef]

30. Martino, R.; Salavert, M.; Parody, R.; Tomás, J.; Vázquez, L.; Jarque, I.; Prieto, E.; Sastre, J.L.; Gadea, I.; Pemán, J.; et al. Blastoschizomyces capitatus infection in patients with leukemia: Report of 26 cases. J. Clin. Infect. Dis. 2004, 38, 335-341. [CrossRef] [PubMed]

31. Schuermans, C.; van Bergen, M.; Coorevits, L.; Verhaegen, J.; Lagrou, K.; Surmont, I.; Jeurissen, A. Breakthrough Saprochaete capitata infections in patients receiving echinocandins: Case report and review of the literature. Med. Mycol. 2011, 49, 414-418. [CrossRef] [PubMed]

32. Arendrup, M.; Boekhout, T.; Akova, M.; Meis, J.; Cornely, O. ESCMID and ECMM joint clinical guidelines for the diagnosis and management of rare invasive yeast infections. Clin. Microbiol. Infect. 2014, 20, 76-98. [CrossRef]

33. Muriel, P.; Sophie, C.; Philippe, L.; Xavier, V.; Caroline, P.; Pamela, C. Concomitant cases of disseminated Geotrichum clavatum infections. Leuk. Lymphoma 2014, 55, 1029-2403.

34. Naples, J.; Martin, A.; Sobelman, D.; Schoem, S. Unusual Fungal Lesion Presenting as a Neoplastic Pediatric Tongue Mass. Pediatrics 2017, 139, e20161345. [CrossRef]

35. Jefferies, S.D.; Ord, R.A. An unusual presentation of oral syphilis. Br. J. Oral Maxillofac. Surg. 1985, 23, 376-380. [CrossRef]

36. Forrestel, A.K.; Kovarik, C.L.; Katz, K.A. Sexually acquired syphilis: Laboratory diagnosis, management, and prevention. J. Am. Acad. Dermatol. 2020, 82, 17-28. [CrossRef]

37. Sharma, S.; Bajpai, J.; Pathak, P.K.; Pradhan, A.; Singh, P.; Kant, S. Oral tuberculosis-Current concepts. J. Family Med. Prim. Care 2019, 8, 1308-1312. [PubMed]

38. Kaplan, I.; Anavi, K.; Anavi, Y.; Calderon, S.; Schwartz-Arad, D.; Teicher, S.; Hirshberg, A. The clinical spectrum of Actinomycesassociated lesions of the oral mucosa and jaw-bones: Correlation with histomorphometric analysis. Oral Surg. Oral Med. Oral Pathol. Oral Radiol. Endod. 2009, 108, 738-746. [CrossRef]

39. Alamillos-Granados, F.J; Dean-Ferrer, A.; García-López, A.; López-Rubio, F. Actinomycotic ulcer of the oral mucosa: An unusual presentation of oral actinomycosis. Br. J. Oral Maxillofac. Surg. 2000, 38, 121-123. [CrossRef] [PubMed]

40. Wang, H.W.; Balakrishna, J.P.; Pittaluga, S.; Jaffe, E.S. Diagnosis of Hodgkin lymphoma in the modern era. Br. J. Haematol. 2019, 184, 45-59. [CrossRef] [PubMed]

41. Silva, T.D.; Ferreira, C.B.; Leite, G.B.; de Menezes Pontes, J.R.; Antunes, H.S. Oral manifestations of lymphoma: A systematic review. Ecancermedicalscience 2016, 10, 665. [CrossRef] [PubMed]

42. Campo, E.; Swerdlow, S.H.; Harris, N.L.; Pileri, S.; Stein, H.; Jaffe, E.S. The 2008 WHO classification of lymphoid neoplasms and beyond: Evolving concepts and practical applications. Blood 2011, 117, 5019-5032. [CrossRef]

43. Hosseinpour, S.; Mashhadiabbas, F.; Ahsaie, M.G. Diagnostic Biomarkers in Oral Verrucous Carcinoma: A Systematic Review. Pathol. Oncol. Res. 2017, 23, 19-32. [CrossRef]

44. Sonalika, W.G.; Anand, T. Oral verrucous carcinoma: A retrospective analysis for clinicopathologic features. J. Cancer Res. Ther. 2016, 12, 142-145. [CrossRef]

45. Almouhawis, H.A.; Leao, J.C.; Fedele, S.; Porter, S.R. Wegener's granulomatosis: A review of clinical features and an update in diagnosis and treatment. J. Oral Pathol. Med. 2013, 42, 507-516. [CrossRef] [PubMed]

46. Huang, M.L.; Wu, Y.Q.; Ruan, W.H. A rare case of pediatric Crohn's disease and alveolar bone loss: A report and review. Transl. Pediatr. 2020, 9, 720-725. [CrossRef] [PubMed]

47. Laube, R.; Liu, K.; Schifter, M.; Yang, J.L.; Suen, M.K.; Leong, R.W. Oral and upper gastrointestinal Crohn's disease. J. Gastroenterol. Hepatol. 2018, 33, 355-364. [CrossRef]

48. Badhey, A.K.; Kadakia, S.; Carrau, R.L.; Iacob, C.; Khorsandi, A. Sarcoidosis of the head and neck. Head Neck Pathol. 2015, 9 , 260-268. [CrossRef]

49. Dhawan, S.R.; Saini, A.G.; Singhi, P.D. Management Strategies of Melkersson-Rosenthal Syndrome: A Review. Int. J. Gen. Med. 2020, 13, 61-65. [CrossRef]

50. Hartwick, R.; Batsakis, J. Sinus aspergillosis and allergic fungal sinusitis. Ann. Otol. Rhinol. Laryngol. 1991, 100, 427-430. [CrossRef]

51. Dreizen, S.; Keating, M.; Beran, M. Orofacial fungal infections. Nine pathogens that may invade during chemotherapy. Postgrad. Med. 1992, 91, 349-364. [CrossRef]

52. Benson-Mitchell, R.; Tolley, N.; Croft, C.; Gallimore, A. Aspergillosis of the larynx. J. Laryngol. Otol. 1994, 108, 83-85. [CrossRef] [PubMed] 
53. Ibáñez-Martínez, E.; Ruiz-Gaitán, A.; Pemán-García, J. Update on the diagnosis of invasive fungal infection. Rev. Esp. Quimioter. 2017, 30, 16-21.

54. Latgé, J. Aspergillus fumigatus and aspergillosis. Clin. Microbiol. Rev. 1999, 12, 310-350. [CrossRef] [PubMed]

55. Denning, D. Invasive aspergillosis. Clin. Infect. Dis. 1998, 26, 781-803. [CrossRef]

56. Dreizen, S. Oral complications of cancer therapies. Description and incidence of oral complications. NCI Monogr. 1990, 9, 11-15.

57. Cano, M.; Hajjeh, R. The epidemiology of histoplasmosis: A review. Sem. Resp. Inf. 2001, 16, 109-118. [CrossRef] [PubMed]

58. Goldman, M.; Johnson, P.; Sarosi, G. Fungal pneumonias. The endemic mycoses. Clin. Chest Med. 1999, 20, 507-519. [CrossRef]

59. Folk, G.A.; Nelson, B.L. Oral Histoplasmosis. Head Neck Pathol. 2017, 11, 513-516. [CrossRef]

60. Fitzpatrick, S.; Cohen, D.; Clark, A. Ulcerated Lesions of the Oral Mucosa: Clinical and Histologic Review. Head Neck Pathol. 2019, 13, 91-102. [CrossRef]

61. Rodríguez-Díaz, E.; Morán-Estefanía, M.; López-Avila, A.; Piris, J.; Fernández-Blasco, G.; García, J.I.; Armijo, M. Clinical expression of secondary syphilis in a patient with HIV infection. J. Dermatol. 1994, 21, 111-116. [CrossRef] [PubMed]

62. Ahmed, S.; Ali, M.; Adegbite, N.; Vaidhyanath, R.; Avery, C. Actinomycosis of tongue: Rare presentation mimicking malignancy with literature review and imaging features. Radiol. Case Rep. 2019, 14, 190-194. [CrossRef]

63. Valour, F.; Sénéchal, A.; Dupieux, C.; Karsenty, J.; Lustig, S.; Breton, P.; Gleizal, A.; Boussel, L.; Laurent, F.; Braun, E.; et al. Actinomycosis: Etiology, clinical features, diagnosis, treatment, and management. Infect. Drug Resist. 2014, 14, 183-189.

64. Verma, A.; Stock, W.; Lait, M.; Ferrer, K.; Quinn, J.; Platanias, L. Actinomycosis presenting as an oral ulcer in a neutropenic patient. South Med. J. 2002, 95, 1105. [CrossRef]

65. Marcoval, J.; Penín, R.M. Histopathological Features of Orofacial Granulomatosis. Am. J. Dermatopathol. 2016, 38, 194-200. [CrossRef] [PubMed]

66. Dignass, A.; Van Assche, G.; Lindsay, J.O.; Colombel, J.F.; Danese, S.; D’Hoore, A.; Gassull, M.; Gomollón, F.; Hommes, D.W.; Michetti, P.; et al. The second European evidence-based consensus on the diagnosis and management of Crohn's disease: Current management. J. Crohn's Colitis 2010, 4, 28-62. [CrossRef] [PubMed] 